\title{
Experimental Investigation of Retrofit Options for Mobile Homes
}

S. J. Ball

\section{MASTER}

\section{OAK RIDGE NATIONAL LABORATORY}




\section{DISCLAIMER}

This report was prepared as an account of work sponsored by an agency of the United States Government. Neither the United States Government nor any agency Thereof, nor any of their employees, makes any warranty, express or implied, or assumes any legal liability or responsibility for the accuracy, completeness, or usefulness of any information, apparatus, product, or process disclosed, or represents that its use would not infringe privately owned rights. Reference herein to any specific commercial product, process, or service by trade name, trademark, manufacturer, or otherwise does not necessarily constitute or imply its endorsement, recommendation, or favoring by the United States Government or any agency thereof. The views and opinions of authors expressed herein do not necessarily state or reflect those of the United States Government or any agency thereof. 


\section{DISCLAIMER}

Portions of this document may be illegible in electronic image products. Images are produced from the best available original document. 


\section{Printed in the United States of America. Available from National Technical Information Service \\ U.S. Department of Commerce 5285 Port Royal Road, Springfield, Virginia 22161 \\ Price: Printed Copy $\$ 4.00$; Microfiche $\$ 3.00$}

This report was prepared as an account of work sponsored by the United States Government. Neither the United States nor the Energy Research and Development Administration/United States Nuclear Regulatory Commission, nor any of their employees, nor any of their contractors, subcontractors, or their employees, makes any warranty, express or implied, or assumes any legal liability or responsibility for the accuracy, completeness or usefulness of any information, apparatus, product or process disclosed, or represents that its use would not infringe privately owned rights. 
Contract No. W-7405-eng-26

Instrumentation and Controls Division

EXPERIMENTAL INVESTIGATION OF RETROFIT OPTIONS FOR MOBILE HOMES

S. J. Ba11

Manuscript Completed - March 3, 1977

Date Published - March 1977

This work was supported by

The Federal Energy Administration and

The Energy Research and Development Administration

Division of Buildings and Industry

Prepared by the OAK RIDGE NATIONAL LABORATORY

Oak Ridge, Tennessee 37830 operated by UNION CARB IDE CORPORATTION

\section{for the}

This report was PUTE

This report was prepared as an account of work aponeored by the United Stalos Covernment. Neither the United States not the United States Energy their employess subcontractors, or theis employees, makes sny warranty, express or implied, or assumes any leget bability or responsibility for the sccuracy, completenes or usefulntes of any information, apparatus, product or process disclosed, or represents that its use would not

ENERGY RESEARCH AND DEVELOPMENT ADMINISTRATION 
THIS PAGE

\section{WAS INTENTIONALLY LEFT BLANK}




\section{ABSTRACT}

A mobile home located (outdoors) in Oak Ridge, Tennessee, was tested to determine its energy-use characteristics for both space heating and cooling. The main objective was to determine the energy savings that can be achieved by the addition of retrofit items such as storm windows, skirting, and extra insulation and how these savings vary with weather conditions. Analyses of space heating data show that energy savings approaching $50 \%$ can be achieved, but analyses of space cooling data were inconclusive. 
THIS PAGE

WAS INTENTIONALLY

LEFT BLANK 


\section{CONTENTS}

$\underline{\text { Page }}$

1. Introduction . . . . . . . . . . . . . . 1

2. Description of Experiments ................ 1

3. Summary of Experiment Conditions . . . . . . . . . 4

4. Instrumentation . . . . . . . . . . . . . . . 7

4.1 RTD Temperature Measurements . . . . . . . . . 8

4.2 Thermocouple l'emperature Measurements . . . . . . 8

4.3 Solar Radiation Measurement ............ 10

4.4 Wind Speed and Direction .............. . 11

4.5 Prec1p1tation .................. 12

4.6 Furnace On-Time and Number-of-Cycles Measurements . . . 12

5. Analysis of Heating Season Data and the

Effects of Retrofits . . . . . . . . . . . . . 12

6. Estimated Economic Gains from Retrofits . . . . . . . 19

7. Conclusions . . . . . . . . . . . . . . . 25

8. Recommendations for Future Work . . . . . . . . . 25

9. References.................... 27

1U. Acknowledgment ................. . 27 


\section{INTRODUCTION}

The primary objectives of the moblle home energy-use experiments were to determine the space heating and cooling characteristics of a 50-ft long, 12-ft wide mobile home "as delivered," and to measure the variation of these characteristics with retrofits. This information can be useful in developing and evaluating changes in proposed mobile home construction standards and in informing mobile home owners about the economics of various improvements. Another objective was to learn more about a mobile home exposed to the weather (i.e., what measurements are required to characterize $i t)$ so that a more comprehensive experimental and analytical program could be planned.

Space heating experiments were conducted both with an electrical resistance-heating, forced-air furnace and with a conventional gas furnace. Analyses of the heating data permitted accurate and repeatable predictions of the differences in energy use (for given weather and controlled mobile home inside temperatures) for the various configurations, i.e., with and without storm windows, skirting, etc. Unfortunately, similar attempts to characterize the energy use for air conditioning led to inconclusive results, and further investigations of this problem are recommended. Only the space-heating experiments will be described in detail in the present report.

\section{DESCRIPTION OF EXPERIMENTS}

The mobile home space-heating experiments required measurements and recordings of electrical or gas furnace heat inputs, inside temperatures, and weather conditions so that an accurate dynamic model of the trailer could be derived. It is important to note that a dynamic, rather than a steady-state model was necessary because the weather constantly changed. Because outside temperature, solar heating, and wind changes caused the heat storage in the trafler structure to vary, and because the furnace had on-off control, "instantaneous" heat balance measurements were not useful. Although averages of steady-state 
data collected over long periods can give fairly accurate energy-use data, usually the accuracy was insufficient for determining the differences due to retrofit items. Apparently, the difficulty was due to the inability of the static model to account for the changes in heat storage in the structure with changes in the weather.

Because a mobile home is not suitable for making accurate measurements, notions such as "comfort of the occupant" should be considered in determining what measurements to make and how to interpret them. For example, if the sun were shining on and into the west end of a mobile home and the central air circulating fan were off, it might be too warm in the west bedroom and too cold in the living room, even though the "mean" Inside temperature would appear to be just right. The question of what measurements to make was resolved by taking more data than was thought necessary. A list of the measurements is shown in Table 1. The question of how to interpret the data was answered by developing a simple method to give consistent and "reasonable" results. Higher-order analyses of temperature distributions within the mobile home were not made, although sufficient data were probably available for this.

The basic measurements made for analysis of the heating requirements were

1. Average inside temperature, averaged from 16 sensors, four each in the approximate centers of the four major living areas (the four sensors in each group were spaced equitably between the floor and ceiling);

2. Furnace and other heat generated inside;

3. Outside dry bulb temperature, by an RTD shaded from the sun, wind, and rain, and located about $50 \mathrm{ft}$ from the mobile home;

4. Wind speed;

5. Solar radiation.

Other conditions, such as rainfall, wet bulb temperature, and wind direction were measured, but their effect was insignificant.

Data was logged at 15-min intervals, $24 \mathrm{hrs} /$ day by a Beckman Dextir data system, stored in digital form on magnetic tape, and processed daily on the ORNL IBM/360 computers. The wind speed and 
Table 1. Tabulation of mobile home measurements logged by the Dextir data system (15-min intervals)

\begin{tabular}{|c|c|c|c|}
\hline Item & Parameter & Sensor type & Comments \\
\hline Furnace & $\begin{array}{l}\text { Percent on-time } \\
\text { Number of cycles } \\
\text { Intake temp. (dry) } \\
\text { Outlet temp. (dry) } \\
\text { West bedroom duct }\end{array}$ & $\begin{array}{l}\text { Op amp } \\
\text { Op amp } \\
\text { RTD, TC } \\
\text { RTD, TC } \\
\text { TC }\end{array}$ & \\
\hline $\begin{array}{l}\text { Mobile } \\
\text { home in- } \\
\text { side }\end{array}$ & $\begin{array}{l}\text { Average air temp. } \\
\text { Air temp. near ceiling } \\
\text { Air temp. near floor } \\
\text { Black-ball temp. } \\
\text { Inside wall temp. } \\
\text { TC reference, junction } \\
\text { Temp. between ceiling. } \\
\text { and roof }\end{array}$ & $\begin{array}{l}\text { RTD } \\
\text { TC } \\
\text { TC } \\
\text { TC } \\
\text { TC } \\
\text { RTD } \\
\text { TC }\end{array}$ & $\begin{array}{l}\text { 16-point average } \\
4 \text { locations } \\
4 \text { locations } \\
\text { Approx. mean } \\
\text { radiant temp. } \\
4 \text { locations }\end{array}$ \\
\hline $\begin{array}{l}\text { Mobile } \\
\text { home out- } \\
\text { side }\end{array}$ & $\begin{array}{l}\text { Outside wall temps. } \\
\text { Roof temp. } \\
\text { Crawl-space temp. }\end{array}$ & $\begin{array}{c}\mathrm{TC} \\
\mathrm{TC} \\
\mathrm{RTD}, \mathrm{TC}\end{array}$ & $\begin{array}{l}4 \text { locations } \\
\text { RTD is } 4 \text {-point } \\
\text { average }\end{array}$ \\
\hline Weather & $\begin{array}{l}\text { Outside dry bulb } \\
\text { Outside wet bulb } \\
\text { Solar radiation } \\
\text { Wind speed } \\
\text { Wind direction } \\
\text { Precipitation }\end{array}$ & $\begin{array}{c}\text { RTD, TC } \\
\text { RTD } \\
\text { Sunbrella } \\
\text { Anemometer } \\
\text { Vane } \\
\text { Level detector }\end{array}$ & $\begin{array}{l}\text { RTD bridge } \\
\text { circuit }\end{array}$ \\
\hline
\end{tabular}

Abbreviations: Op amp, operational amplifier; RTD, resistance temperature detection; and TC, thermocouple. 
furnace heat input were integrated over the sampling interval because instantaneous measurements generally were not typical of the averages. Since the outside temperature and solar radiation signals changed slowly, their instantaneous readings were satisfactory. The inside average temperature responded more rapldly when the furnace and fan were turned on; consequently, when the furnace cycled on $\sim 15$-min periods, the differences between the instantaneous readings and the true averages were as much as $1-2^{\circ} \mathrm{F}$.

Certain aspects of this experiment should be compared with two other possibilities: collecting data from a mobile home in a climate chamber and from an inhabited mobile home (Table 2). On the one hand, perhaps the most significant difference between tests of an exposed mobile home and one in a climate chamber (cloistered) is that the heat loss from an exposed home must be measured indirectly by fitting a dynamic model; but, because the conditions can be controlled in a climate chamber, steady-state measurements are useful. On the other hand, tests of an exposed mobile home are a better simulation of real situations, that is, actual weather conditions and measurement problems are encountered. Solutions of these problems are prerequisites to analyses of an inhabited mobile home.

\section{SUMMARY OF EXPERIMENT CONDITIONS}

The mobile home tested (Fig. 1) was $12 \mathrm{ft}$ wide and $50 \mathrm{ft}$ long. It had been obtained on surplus from the HUD Pennsylvania Flood Relief Program following hurricane Agnes. It was constructed to 1971 MHMA standards and equipped with a Coleman gas furnace having an input rating of $70,000 \mathrm{Btu} / \mathrm{hr}$. The thermal insulation was 2-in.-thick (nominal) glass fiber batting in the ceiling, walls, and floor.

The home was installed at the test site in January 1974, with the kitchen facing east. After preliminary tests were completed with minimal instrumentation, an electric furnace with variable voltage control was installed in February 1974. Following installation and calibration of all mobile home and weather instrumentation by mid-March, several week-long experiments were run with the furnace operated in 
Table 2. Comparison of mobile home tests

\begin{tabular}{|c|c|c|c|}
\hline \multirow{2}{*}{ Consideration } & \multicolumn{3}{|c|}{ Type of mobile home test } \\
\hline & Cloistered & Exposed & Inhabited \\
\hline Heat loss measurements & Can be made direct $1 y$ & Must be indirect & Must be indirect \\
\hline $\begin{array}{l}\text { Experimental flexi- } \\
\text { bility }\end{array}$ & $\begin{array}{l}\text { Al1 conditions control- } \\
\text { lable }\end{array}$ & $\begin{array}{l}\text { All but weather control- } \\
\text { lable }\end{array}$ & Dependent on residents \\
\hline $\begin{array}{l}\text { Usefulness of results } \\
\text { (all types are limited } \\
\text { to peculiarities of } \\
\text { the mobile home being } \\
\text { tested) }\end{array}$ & $\begin{array}{l}\text { Measurement errors are } \\
\text { minimized, but weather } \\
\text { and inhabitant effects } \\
\text { are approximate }\end{array}$ & $\begin{array}{l}\text { Measurement errors may } \\
\text { be small; limited to } \\
\text { local weather; inhabi- } \\
\text { tant effects are approx- } \\
\text { imate }\end{array}$ & $\begin{array}{l}\text { Measurement errors great- } \\
\text { est due to lack of exper- } \\
\text { iment control; limited to } \\
\text { local weather; dependent } \\
\text { on inhabitant habits }\end{array}$ \\
\hline Cost & $\begin{array}{l}\text { Most expensive due to } \\
\text { climate chamber costs }\end{array}$ & $\begin{array}{l}\text { Instrumentation and } \\
\text { analysis costs are } \\
\text { major items }\end{array}$ & $\begin{array}{l}\text { Modest cost per mobile } \\
\text { home, but need many tests } \\
\text { to get good statistics }\end{array}$ \\
\hline
\end{tabular}




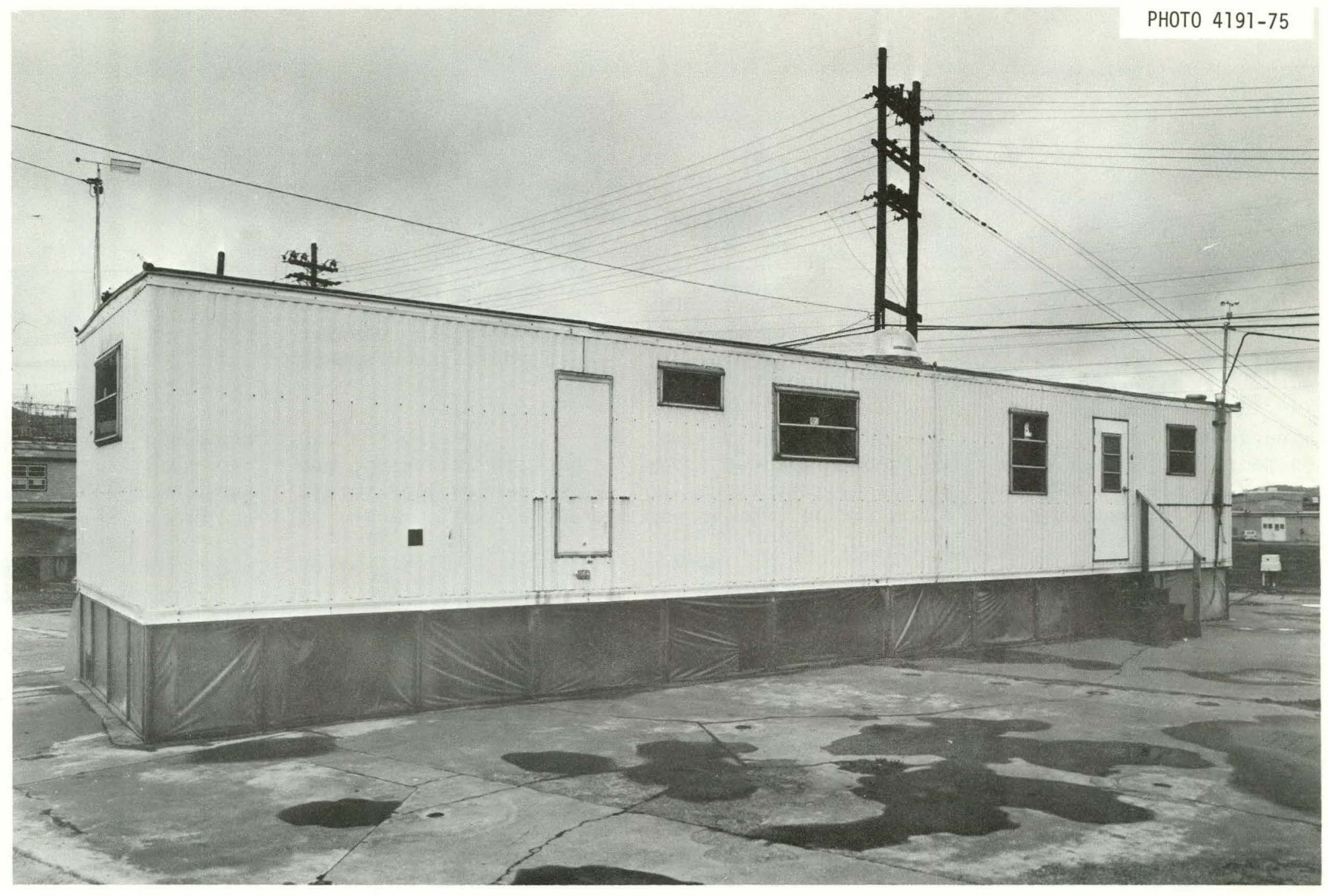

Fig. 1. Mobile home at test site, Oak Ridge, Tennessee. 
various control modes, with and without storm windows. Heating tests were carried out during much of April, although periodic warm spells interrupted the tests.

A $30,000 \mathrm{Btu} / \mathrm{hr}$ central air conditioner unit was installed in the mobile home in July 1974. To determine the rate of heat removal by the unit, the dry and wet bulb temperatures at its intake and outlet and its air flow rate were recorded. Throughout the summer, longterm tests were made at two different fan speeds, with and without storm windows.

The gas furnace was connected to a propane tank in mid-December 1974 for a second series of heating tests. These included long-term (7 to 10 day) tests with combinations of operating modes and retrofit items. In mid-January 1975, skirting was installed. The skirting was made by tacking 6-mil polyethelene sheets to a wood frame, leaving $\sim 1-\mathrm{ft}^{2}$ vents on all four sides (for ventilation and escape of leaking gas). In mid-March 1975, additional insulation was blown into the ceiling and all four walls (but not the floor) with a special blower to ensure that all the wall and ceiling cavities were filled. The insulation was a relatively high-density cellulose-fiber (tradename Thermocon); its claimed R-value rating is five per inch of thickness.

In addition to the retrofit items, tests were run both with automatic fan operation and with the fan on continuously.

\section{INSTRUMENTATION}

Most of the instrumentation installed in February 1974 had been salvaged from other completed projects at ORNL. However, some highquality instruments were acquired: platinum-nickel, resistancetemperature detectors (RTDs); an electronic differential-pressure cell for precipitation measurements; two 12-point strip chart recorders; and a rotating-cup anemometer for wind speed. Three plug-in operational amplifier manifolds were also available for the tests. A Dextir data system was used to digitize and store the data. The measurements made routinely for the heating tests are listed in Table 1. A discussion of each type of measurement follows. 


\subsection{RTD Temperature Measurements}

An operational amplifier bridge cịcuit converted the RTD resistance to a voltage signal compatible with requirements of the Dextir data system. (A typical RTD circuit is shown in Fig. 2.) The bias adjustment was set initially so that the amplifier output was zero when the reference bridge circult was substituted for the RTD leg of the bridge. The circuit was calibrated by monitoring its output (using the Dextir system) with the sensor at several temperatures. The output was linear in the temperature range of interest.

One disadvantage of this system was that the amplifier outputs were sensitive to the total number of RTD bridge circuits used, since they all used a common reference bridge. The long-term drift errors $\left(\sim 1^{\circ} \mathrm{F}\right.$ in several weeks) were also significant if the biases were not readjusted periodically.

Average temperatures in the crawl space and inside the mobile home were monitored using a series-parallel network of RTDs shown in Fig. 3 .

A circuit such as Fig. 3 was used to average the four crawl-space readings. The inside temperature was taken as the average resistance of 16 RTDs (a four-element bridge was substituted for each of the four resistances shown).

The outcide dry bulb tempcraturc was measured in an inveited styrofoam picnic cooler placed in a grassy area $50 \mathrm{ft}$ from the mobile home. The lower face of the cooler was $3 \mathrm{ft}$ from the ground, giving good protection from the sun, wind, and rain. The wet bulb temperature was measured using an RTD with a wick and water reservoir just upstream from an exhaust fan in the cooler. Similar wet-bulb measurements were made inside the mobile home to monitor the performance of the air conditioner.

\subsection{Thermocouple Temperature Measurements}

All 24 Chromel-Alumel thermocouple (TC) signals were recorded by the Dextir system in paralle1 with two 12-point strip chart recorders which had built-in reference junctions. (Later, only the 12 most useful 


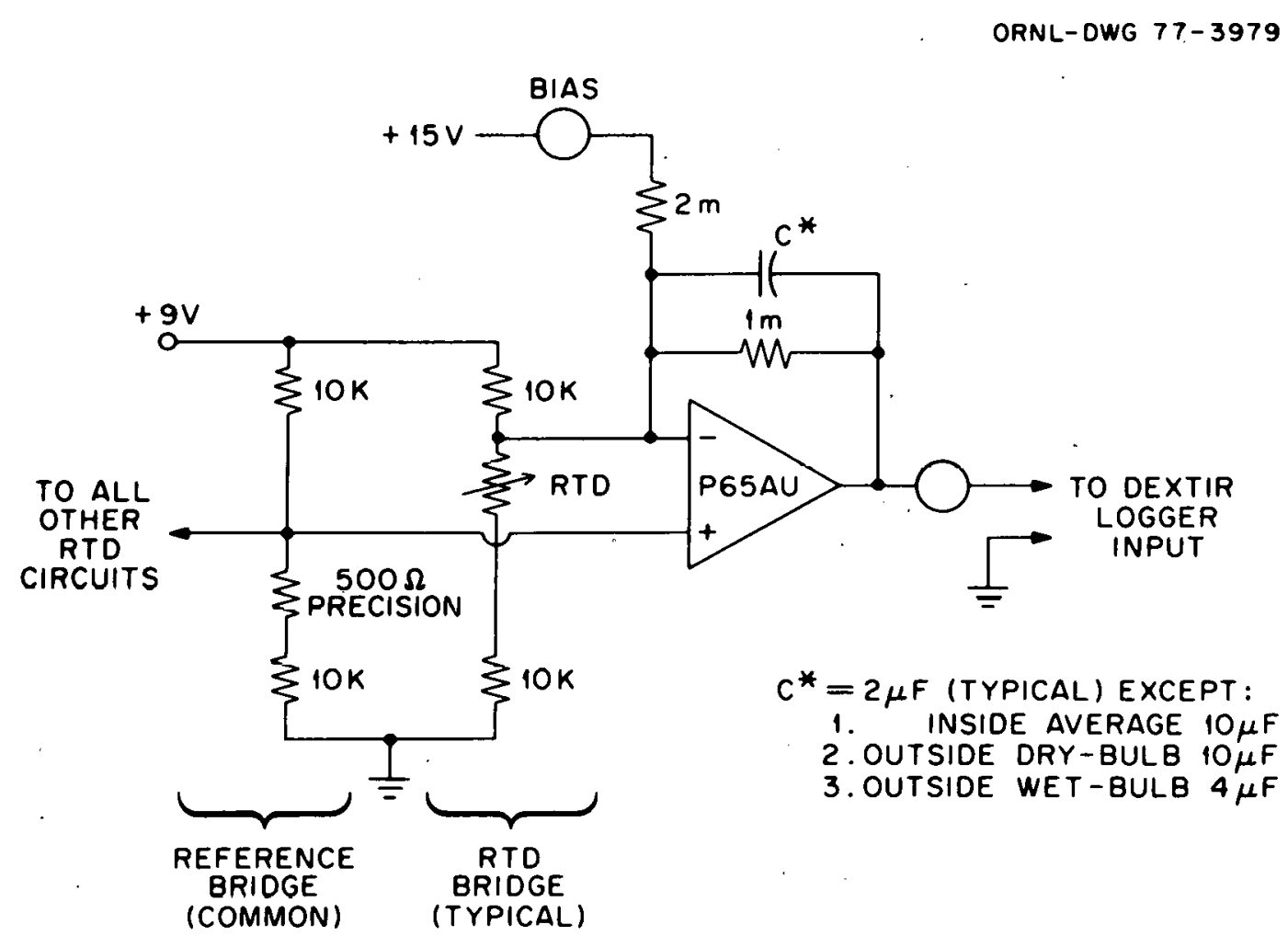

Fig. 2. Typical circuit for resistance temperature detector (RTD).

ORNL-DWG $77-3980$

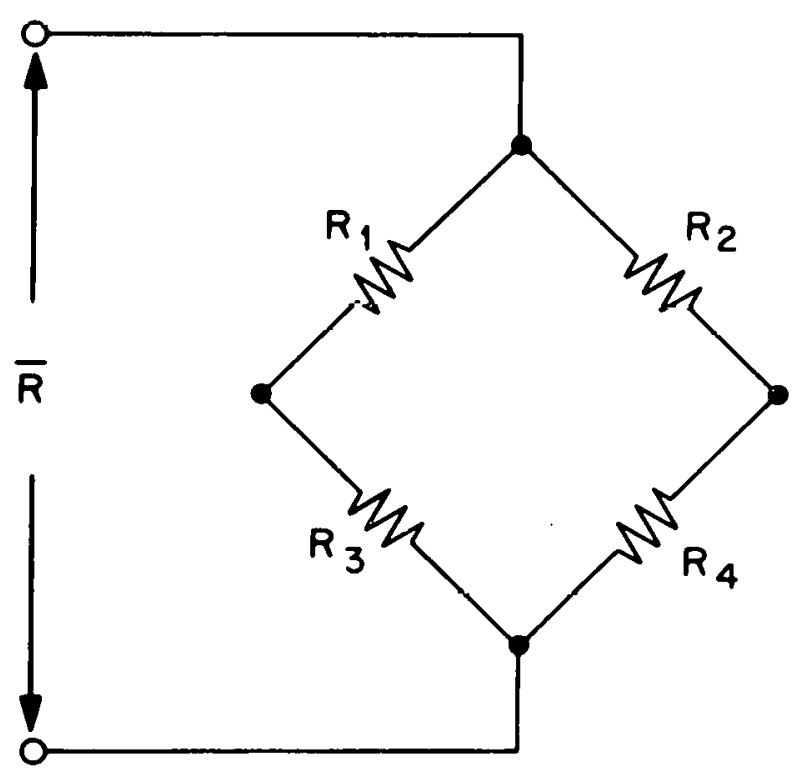

$\bar{R} \approx \frac{R_{1}+R_{2}+R_{3}+R_{4}}{4}$

IF R'S ARE NEARLY EQUAL.

Fig. 3. RTD averaging circuit. 
temperatures were recorded on one strip chart to reduce the amount of data.) The reference junction for Dextir TC signals was a "floating" one. All junctions were placed in a large vacuum flask, along with an RTD to measure the reference temperature. The difference between the thermocouple (sensor) and reference temperatures produced a millivolt signal which was fitted to a conversion equation with an accuracy of $\leq 0.3^{\circ} \mathrm{F}$ for temperatures within $60^{\circ} \mathrm{F}$ of the reference. This procedure avoided the nuisance problems with ice bath references and the $\sim 1^{\circ} \mathrm{F}$ cycling problems with the oven-type reference junctions that were available.

\subsection{Solar Radiation Measurement}

The solar radiation monitor sensed the total radiation incident on the mobile home. This was done with a clear plastic bubble umbrella ("sunbrella"), two aluminum bricks with the same shape and orientation as the mobile home, and two RTDs in a temperature-difference bridge circuit (Fig. 4). The top brick, painted black, was exposed to the sun

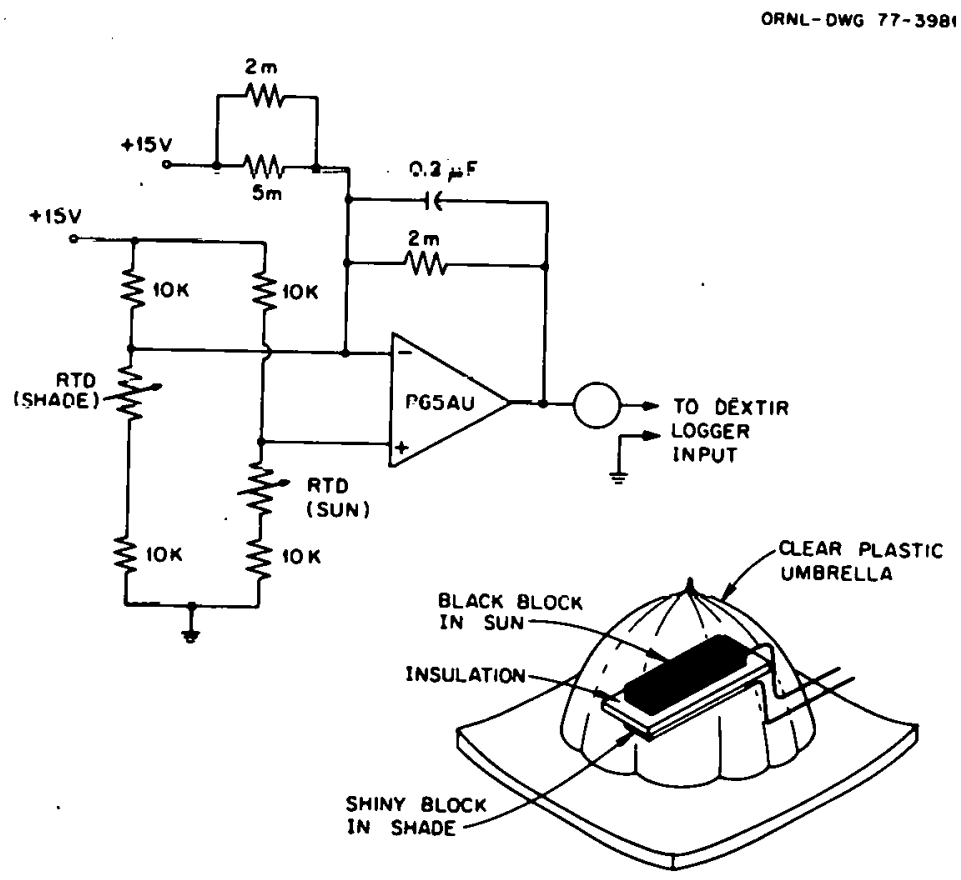

Fig. 4. Sketch and circuit for "sumbrella" solar radiation measurement. 
so that its temperature difference relative to that of the shiny block located below in the shade would be due solely to solar radiation, since both bricks experienced the same ambient temperature. The umbrella was a wind and rain shield. To test the device and to derive a calibration factor, the detector output signal (millivolts, representing temperature difference) was compared with the calculated total solar heating on the mobile home for a clear day (Fig. 5). Since the shapes of the two curves are nearly identical, a conversion constant (kBtu/mv) could be derived. Significantly large negative readings (indicating radiative losses to the sky) were measured at night; these were factored into the analysis.

\subsection{Wind Speed and Direction}

Wind speed was monitored by a four-cup, rotating vane anemometer. The shaft of the anemometer was coupled to a cylindrical shade with two slots through which a light source shined on a photoreststor twice per revolution. The photoresistor drove a one-shot multivibrator

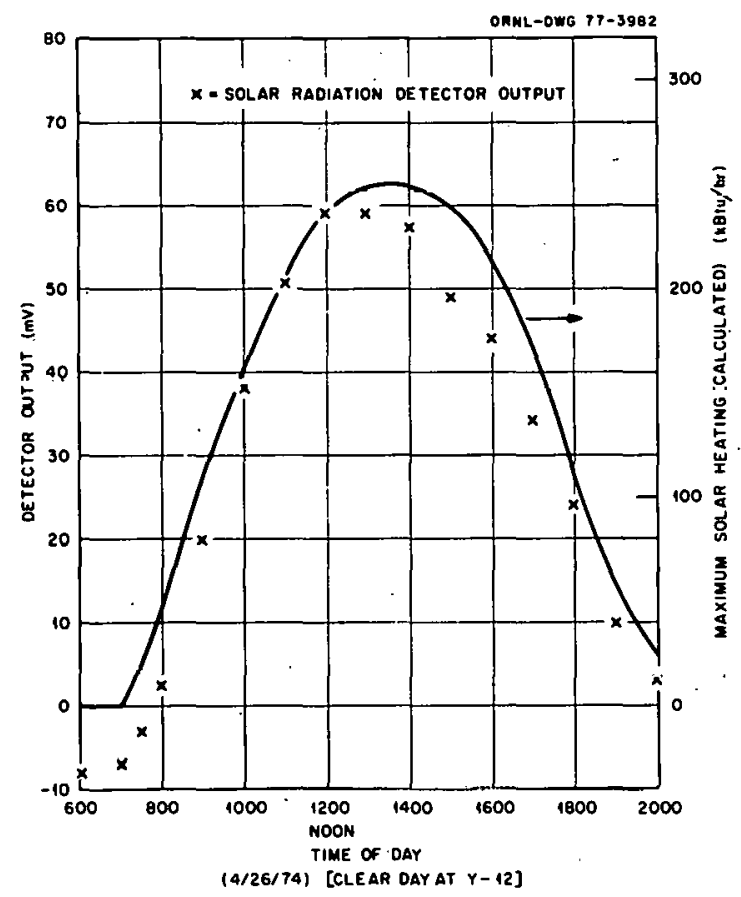

Fig. 5. Clear-day claibration of sunbrella. 
circuit, the output of which (constant-time-width pulses) was integrated over each 15-min sampling period.

Wind direction was monitored by a wind vane coupled to a 10-turn potentiometer. This was not entirely satisfactory, however, because the potentiometer would get wound up and go off scale every several days. [A continuous, $360^{\circ}$ pot (which was not available) would have been preferred.]

\subsection{Precipitation}

Rainfall was monitored by an electronic differential pressure $(d / p)$ cell that measured the water level in a 2-in.-ID, 53-in.-tall Plexiglas tube. A 6.2-in. diam aluminum cone inserted in the top of the tube gave a catch-to-collection area ratio of $9.61: 1$, thus increasing the sensitivity of the level measurement. The resolution of the measurement was $\sim 0.01 \mathrm{in}$. of rainfall. Although the $d / p$ cell was inside the mobile home to inhibit freezing, the water in the outside lines and tubes did freeze several times during the winter, temporarily causing erroneous readings.

\subsection{Furnace On-Time and Number-of-Cycles Measurements}

The circuit shown in Fig. 6 integrated the total furnace (or air conditioner) on-time during a 15-min sample period and counted the number of times the furnace was turned on. The integrators were reset automatically after each reading.

\section{ANALYSIS OF HEATING SEASON DATA AND THE EFFECTS OF RETROFITS}

The dynamic model of the mobile home used to analyze the data was derived empirically. Initially, a single-node model was used, but it was soon evident from model-fitting runs that there was enough heat storage in the outer mobile home structure to cause a significant delay in the transfer of heat to the inside. Next, a two-node model was tried and found adequate; that is, the theoretical, or computed, inside temperatures vs time usually could be made to fit the measured temperatures 


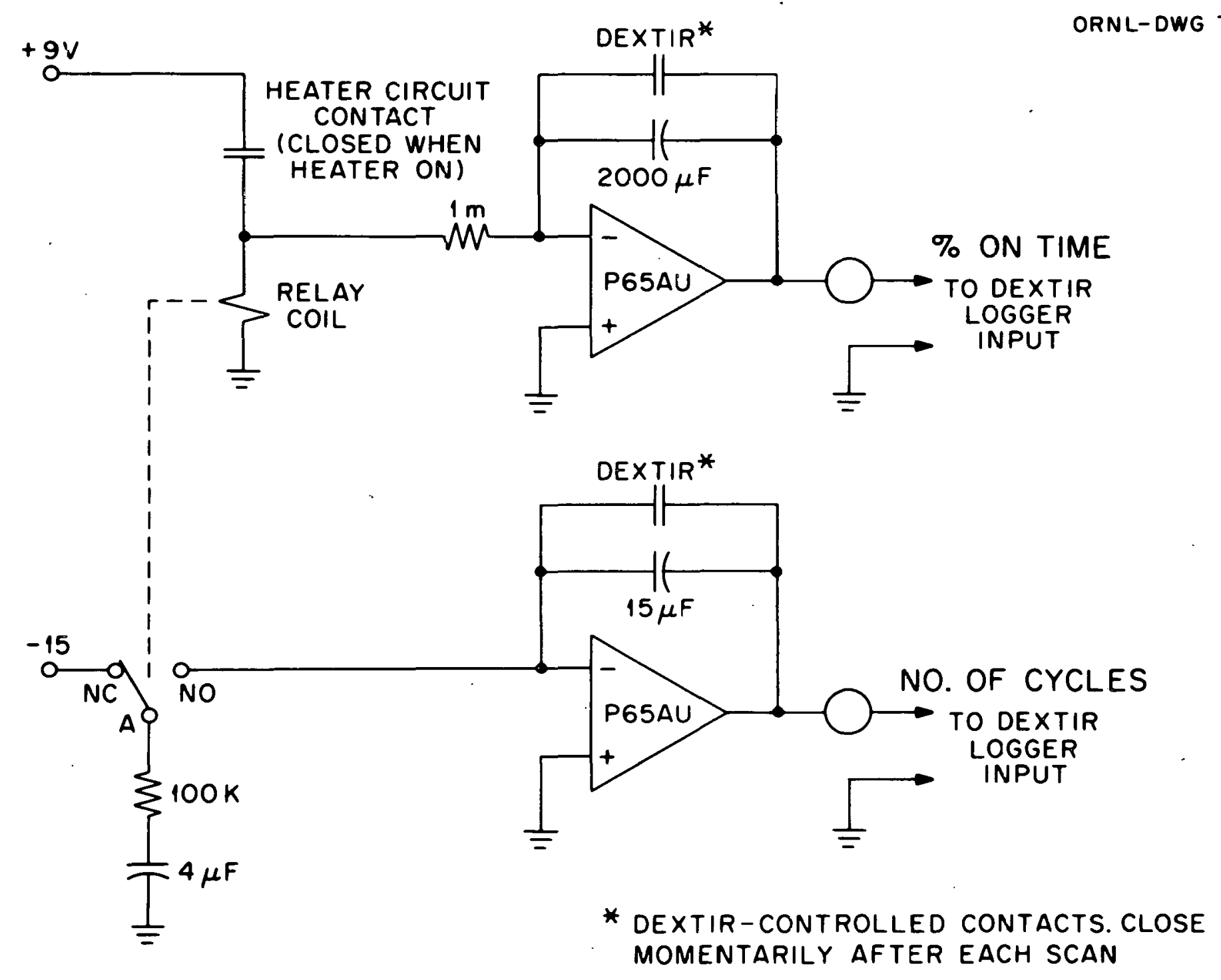

Fig. 6. Circuits for heater percent on-time and number of cycles. 
to within $\sim 1^{\circ} \mathrm{F}$. Figure 7 shows a block diagram of the two-node model, which is described by the following equations:

$$
\left(M C_{p}\right) \frac{d T_{I}}{d t}=U A_{I-S}\left(T_{S}-T_{I}\right)+U A_{I N F I L}\left(T_{O}-T_{I}\right)+Q_{I} \text {, }
$$

and

$$
\left(M_{p}\right)_{S} \frac{d T_{S}}{d t}=U A_{I-S}\left(T_{I}-T_{S}\right)+U A_{0}\left(T_{0}-T_{S}\right)+K_{4} Q_{S U N} \text {, }
$$

where

$$
\begin{aligned}
& \left(\mathrm{MC}_{\mathrm{P}}\right)_{\mathrm{I}, \mathrm{S}}=\text { inside }(\mathrm{I}) \text { and structure }(\mathrm{S}) \text { heat capacities, } \mathrm{Btu} /{ }^{\circ} \mathrm{F} \text {, } \\
& \mathrm{T}_{\mathrm{I}}=\text { average inside temperature, }{ }^{\circ} \mathrm{F} \text {, } \\
& \mathrm{t}=\mathrm{time}, \mathrm{hr} \text {, } \\
& \mathrm{UA}_{I-S}=\text { overall effective heat transfer coefficient times } \\
& \text { area (UA) for heat transfer between the inside and }
\end{aligned}
$$

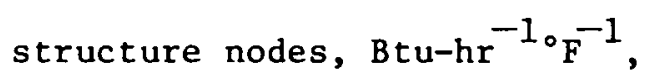

$$
\begin{aligned}
& \mathrm{T}_{\mathrm{S}}=\text { average structure temperature, }{ }^{\circ} \mathrm{F} \text {, } \\
& \mathrm{UA}_{\text {INFIL }}=\text { nvera } 11 \mathrm{HA} \text { for heat transfer due to infiltration } \\
& \equiv \mathrm{K}_{1}+\mathrm{K}_{2} \mathrm{~W}^{2} \text {, Btu-hr }{ }^{-1 \circ} \mathrm{F}^{-1} \text {, } \\
& \mathrm{W}=\text { wind speed (averaged over 15-min interval), mph, } \\
& \mathrm{T}_{0}=\text { outside (dry bulb) temperature, }{ }^{\circ} \mathrm{F} \text {, } \\
& Q_{I}=\text { sum of heat rate inputs to inside, } \\
& =\mathrm{Q}_{\mathrm{H}}+\mathrm{Q}_{\mathrm{SS}}+\mathrm{K}_{6} \mathrm{Q}_{\mathrm{SUN}}-\mathrm{Q}_{\mathrm{HL}}, \mathrm{Btu} / \mathrm{hr} \text {, } \\
& \mathrm{Q}_{\mathrm{H}}=\text { heater input (averaged over 15-min interval), Btu/hr, } \\
& \mathrm{Q}_{\mathrm{SS}}=\text { steady-state heat inputs from'lights, blower, instru- } \\
& \text { mentation, etc., Btu/hr, } \\
& \mathrm{Q}_{\text {SUN }}=\text { total solar heat available (or radiative losses), } \\
& \text { Btu/hr, }
\end{aligned}
$$


ORNL-DWG $77-3984$

MODEL COMPUTES THE INSIDE

TEMPERATURE FOR COMPARISON

WITH THE MEASURED TEMPERATURE

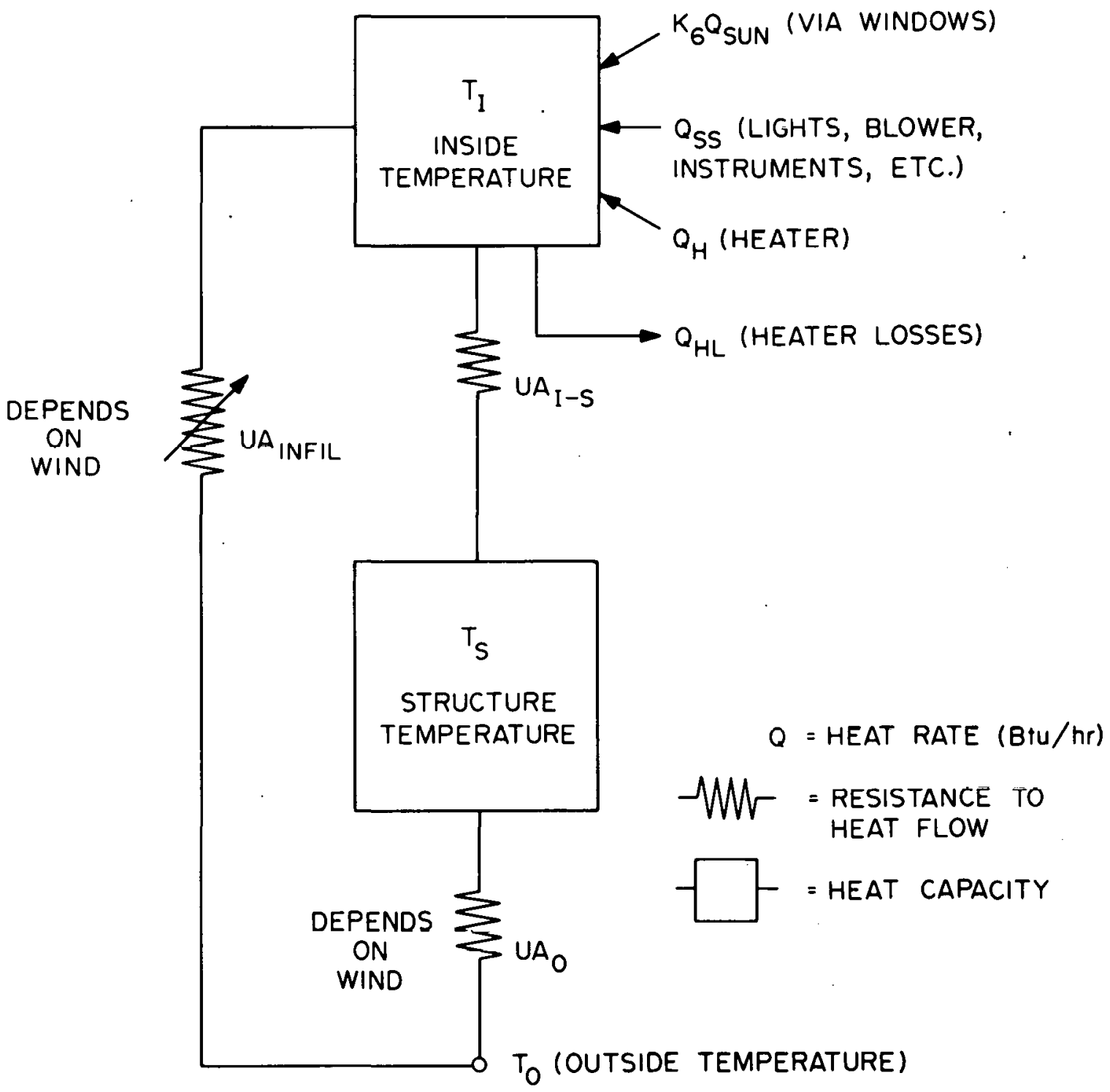

Fig. 7. Diagram of the mobile home experiment computer model. 


$$
\begin{aligned}
\mathrm{Q}_{\mathrm{HL}}= & \text { heater losses (due to losses through ducting, etc.), } \\
= & \mathrm{K}_{5}\left(\mathrm{~T}_{\mathrm{I}}+\Delta \mathrm{T}_{\mathrm{H}}-\mathrm{T}_{0}\right)^{*}, \mathrm{Btu} / \mathrm{hr}, \\
\Delta \mathrm{T}_{\mathrm{H}}= & \text { temperature rise across heater, }{ }^{\circ} \mathrm{F}, \\
\mathrm{UA}_{0}= & \text { overall UA for heat transfer between structure and } \\
& \text { outside, } \\
= & \mathrm{K}_{7}+\mathrm{K}_{3} \mathrm{~W}, \mathrm{Btu} / \mathrm{hr} .
\end{aligned}
$$

The unknown model coefficients, $\mathrm{K}_{1}-\mathrm{K}_{7}, \mathrm{UA}_{\mathrm{I}-\mathrm{S}}$, and $\left(\mathrm{MC}_{\mathrm{p}}\right)_{\mathrm{I}, \mathrm{S}}$, were varied to produce an optimum fit using the optimization code RANøPT, which is based on a method suggested by Hooke and Jeeves.' Typically, data for a 7- to 10-day continuous run were used, and RMS errors of computed (vs measured) inside mean temperatures were $\sim 1.1$ to $1.4^{\circ} \mathrm{F}$. For runs with the same mobile home configuration but over different time periods (different weather inputs), the total heat loss vs temperature difference characteristics were almost the same (i.e., to within $\sim 1 \%)$. These results added confidence to the calculation of the small percentage (5-25\%) of energy savings realized by the addition of individual retrofit items.

Figure 8 shows part of a typical printer-plotted output generated by the RANØPT code which plots the measured (M) vs computed (C) inside temperatures as a function of time.

Results of the retrofit runs w1th gas furnace heat are summarized in Fig. 9, which shows calculated steady-state heat-loss vs $\Delta T$ values with no sun or wind loads. The effects of storm windows, skirting, added insulation in the ceiling and wall cavities, and automatic (cylcic) vs continuous blower operation can be noted. It is significant that after all of the retrofits had been added and the blower operating mode had been changed the heat loss was almost halved for a given steady-state, inside-to-outside temperature difference. However, these steady-state results, without the dynamic effects of weather changes,

\footnotetext{
${ }^{*}$ After skirting was added, the measured temperature in the crawl space was substituted for $\mathrm{T}_{0}$.
} 


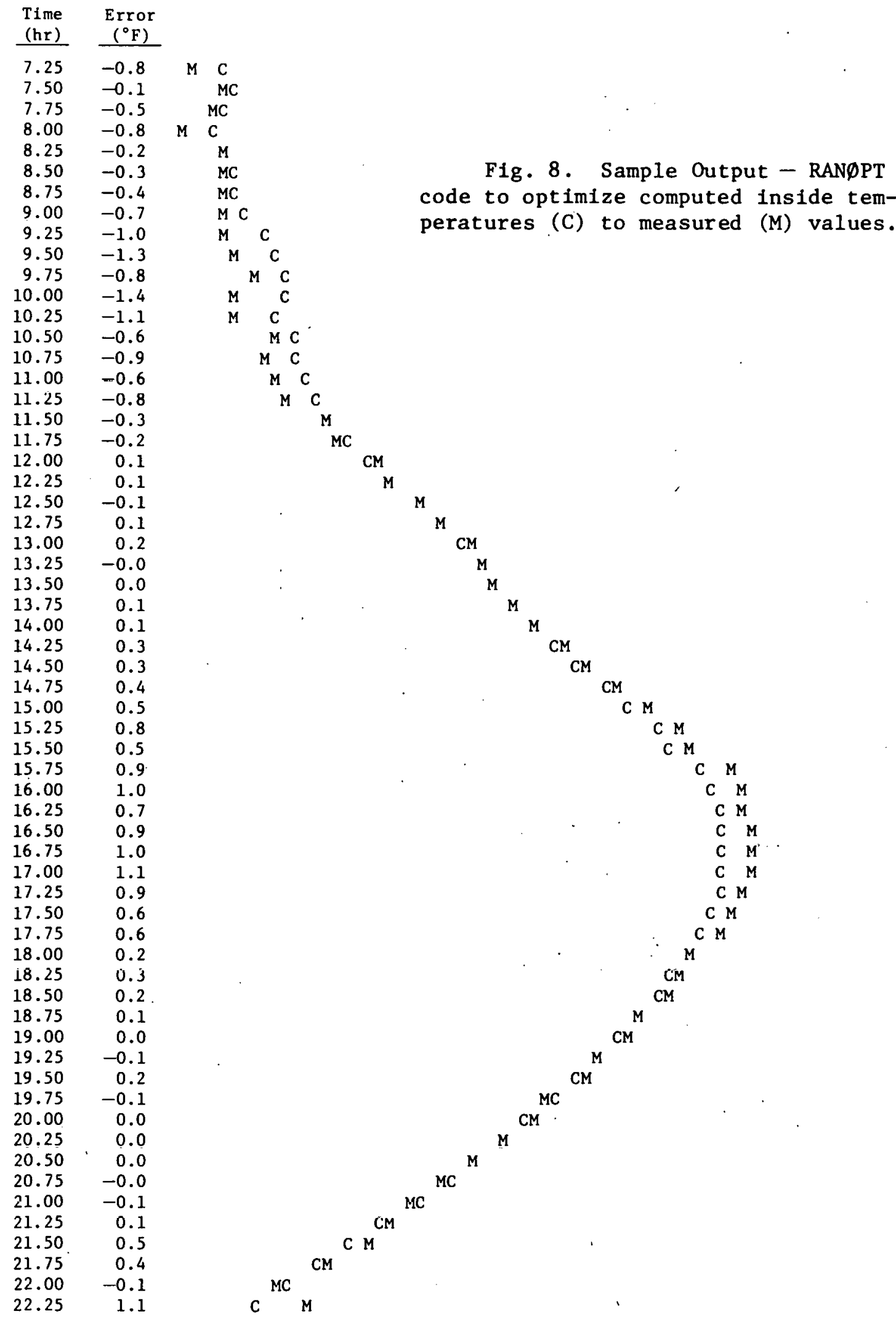


ORNL-OWG 77-3986

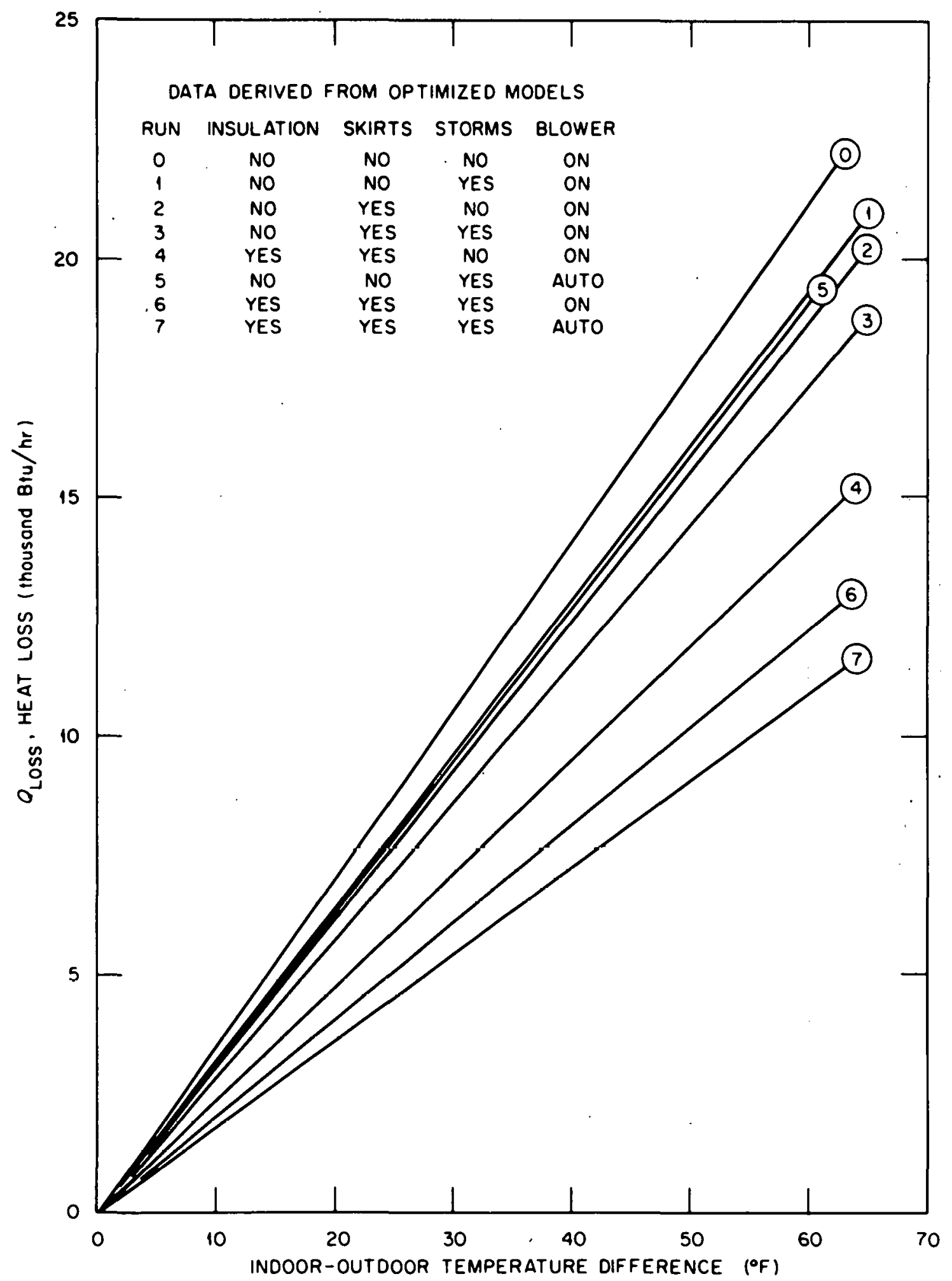

Fig. 9. Mobile home experimental heat loss vs $\Delta T$ (steady-state) data derived from optimized models. 
solar loading, and wind losses may not give accurate seasonal heat loss information.

\section{ESTIMATED ECONOMIC GAINS FROM RETROFITS}

The results shown in Fig. 9 can be used to calculate the approximate annual heating season energy requirements for the basic mobile home and the energy savings that could be expected from the modifications, neglecting solar heating and wind speed.

The commonly used degree-day forumla for estimating annual heating requirements for a bullding is

$$
\mathrm{Q}_{\mathrm{AHL}}=24 \frac{\mathrm{HL}_{\mathrm{d}}}{\Delta \mathrm{T}_{\mathrm{d}}} \mathrm{DD} \text {, }
$$

where

$$
\begin{aligned}
\mathrm{Q}_{\mathrm{AHL}} & =\text { annual heat loss, Btu/yr, } \\
\mathrm{HL}_{\mathrm{d}} & =\text { hourly heat loss at design conditions, Btu/hr, } \\
\Delta \mathrm{T}_{\mathrm{d}} & =\text { design indoor-to-outdoor temperature difference, }{ }^{\circ} \mathrm{F}, \\
\mathrm{DD} & =\text { annual degree-days, }{ }^{\circ} \mathrm{F} \text {-days year }{ }^{-1} .
\end{aligned}
$$

The fraction $H L_{d} / \Delta T_{d}$ is the slope of the line for any given configuration in Fig. 9. When $\mathrm{HL}_{\mathrm{d}}$ is replaced by the product of an overall effective heat loss coefficient, $\mathrm{U}_{\mathrm{OE}}\left(\mathrm{Btu}-\mathrm{ft}^{-2} \mathrm{hr} \mathrm{r}^{-1} \mathrm{~F}^{-1}\right.$ ), the total shell area of the mobile house, $A_{T}\left(\mathrm{ft}^{2}\right)$, and the design temperature difference, $\Delta T_{d}$, Eq. (3) becomes

$$
\mathrm{Q}_{\mathrm{AHL}}=24 \mathrm{U}_{\mathrm{OE}} \mathrm{A}_{\mathrm{T}} \mathrm{DD}
$$

The slopes, and therefore the values of $\mathrm{U}_{O E}{ }^{A_{T}}$, for the configuraclons In Fig. 9 having the highest (basic mobile home) and loweet (with all of the modifications) heat loss are 352.5 and 180 , respectively. Since $A_{T}$ of the mobile home is $2068 \mathrm{ft}^{2}$, the highest and lowest values of $\mathrm{U}_{\mathrm{OE}}$ are 0.170 and $0.087 \mathrm{Btu}-\mathrm{ft}^{-2} \mathrm{hr}^{-1} \mathrm{~F}^{-1}$, respectively. 
In a location having 4000 degree-days per year, the estimated heat loss from the basic mobile home would be $33.8 \mathrm{MBtu} / \mathrm{yr}$, and from the fully modified mobile home, $17.3 \mathrm{MBtu} / \mathrm{yr}$.

Separation of the savings attributable to individual retrofit items were also approximated from the data shown in Fig. 9. When the approximated savings due to several retrofits were combined, the sum did not always equal the sum of the individually measured savings, but the agreement was reasonably good. Table 3 shows approximate percentage of energy savings for individual items. The values under "Error Band" correspond to the discrepancies noted above. Also shown is the reduction in $\mathrm{U}_{\mathrm{OE}} \mathrm{A}_{\mathrm{T}}$ that results from each individual item.

When these measured energy savings are compared with savings for storm windows and reinsulation derived from predictions based on calculations by Wilson, ${ }^{2}$ the comparisons are generally fair to good, depending somewhat on the location (i.e., total degree days). The measured savings for storm windows was about $75 \%$ of the predicted values. The measured savings for reinsulation was considerably higher than the predicted values (a factor of about 2) if the effects of reduced infiltration losses are not considered. Tests of the mobile home infiltration losses before and after reinsulation, however, showed a reduction of about one third (with a $6 \mathrm{mph}$ wind) due to the insulation, and could account for most of this difference.

The wide (2.5\%) error band in Table 3 for "Auto-fan operation" (vs running continuously) makes the estimated savings value somewhat suspect. When combined with storm windows alone, Auto-fan operation showed very little savings compared to when it was combined with storms, skirting, and extra insulation. Some of this difference may be explained as follows: in the first case (auto-fan operation plus storm windows only), the furnace is turned on a larger fraction of the total time, and in the limit there would be no difference between automatic and continuous fan operation with the furnace on full time.

The initial cost for each of the retrofit items will vary with the quality of the item, the mobile home's location, and the extent to which the mobile home occupant is willing to undertake certain of the retrofitting jobs as do-it-yourself projects. In addition, the initial 
Table 3. Separation of retrofit item savings - heating season

\begin{tabular}{lccc}
\hline Retrofit Item & $\begin{array}{c}\text { Savings } \\
(\%)\end{array}$ & $\begin{array}{c}\text { Error band } \\
(\%)\end{array}$ & $\begin{array}{c}\text { Reduction in } \\
\mathrm{U}_{\mathrm{OE}} \mathrm{A}_{\mathrm{T}} \\
\left(\mathrm{Btu}_{\mathrm{hr}}^{-1} \mathrm{~F}^{-1}\right)\end{array}$ \\
\hline Storm windows & 8.6 & $<1$ & 30.5 \\
Skirting & 12.1 & $<1$ & 42.5 \\
Added insulation & 23.7 & 1.4 & 83.5 \\
Auto-fan operation & 4.5 & 2.5 & 16.0 \\
\hline
\end{tabular}

${ }^{a}$ Total storm window area $=72 \mathrm{ft}^{2}$. 
costs of the retrofits and the remaining lifetime of the mobile home over which the inftial cost of the retrofits can be recovered through lower heating costs can vary widely. For example, storm windows made from clear plastic sheeting and masking tape could be installed by the owner for less than $\$ 10$; the cost recovery time would be short. However, custom-made glass storm windows, with installation, could cost several hundred dollars, and the cost recovery time could exceed the remaining lifetime of the mobile home.

The energy conservation and economic values of each retrofit item can be determined from Fig. 10, which shows estimated reductions in the annual heat loss and the annual heating cost as a function of climate. Heating cost savings are shown for the mobile home heated by electricity costing $4 \mathrm{c} / \mathrm{kWhr}$, and by propane costing $45 \mathrm{c} / \mathrm{gal}$ (propane furnace efficiency of $60 \%$ is assumed). For an alr conditioned mobile home, substantial additional energy savings would be realized from the retrofits during the cooling season, but the amounts could not be estimated accurately from the present data. Analysis of the cooling data showed savings of 30 to $35 \%$ for the extra insulation (with moderate sun loads), but the results were neither consistent nor very reproducible. It is important to note that the costs of adding insulation and (standard) storm windows to an older moblle home are higher than the additional costs for the same items installed in a factory on a new mobile home. Hence, retrofit items experimentally determined to be economical would be worthwhile items for incorporation in new factory-built mobile homes.

Estimates of the times required for heating season savings to pay back the cost of various retrofit items are given in Table 4 . The assumptions incorporated into these results are the data (Table 3 ), a $12 \%$ annual interest rate, a 4000 degree-days heating season, and $4 \mathrm{c} / \mathrm{kWhr}$ electricity used for heating. The time $\mathrm{T}$ (yrs) required to pay back a loan of $P$ dollars with an annual interest rate of $I$ percent 
ORNL-DWG 77-3987

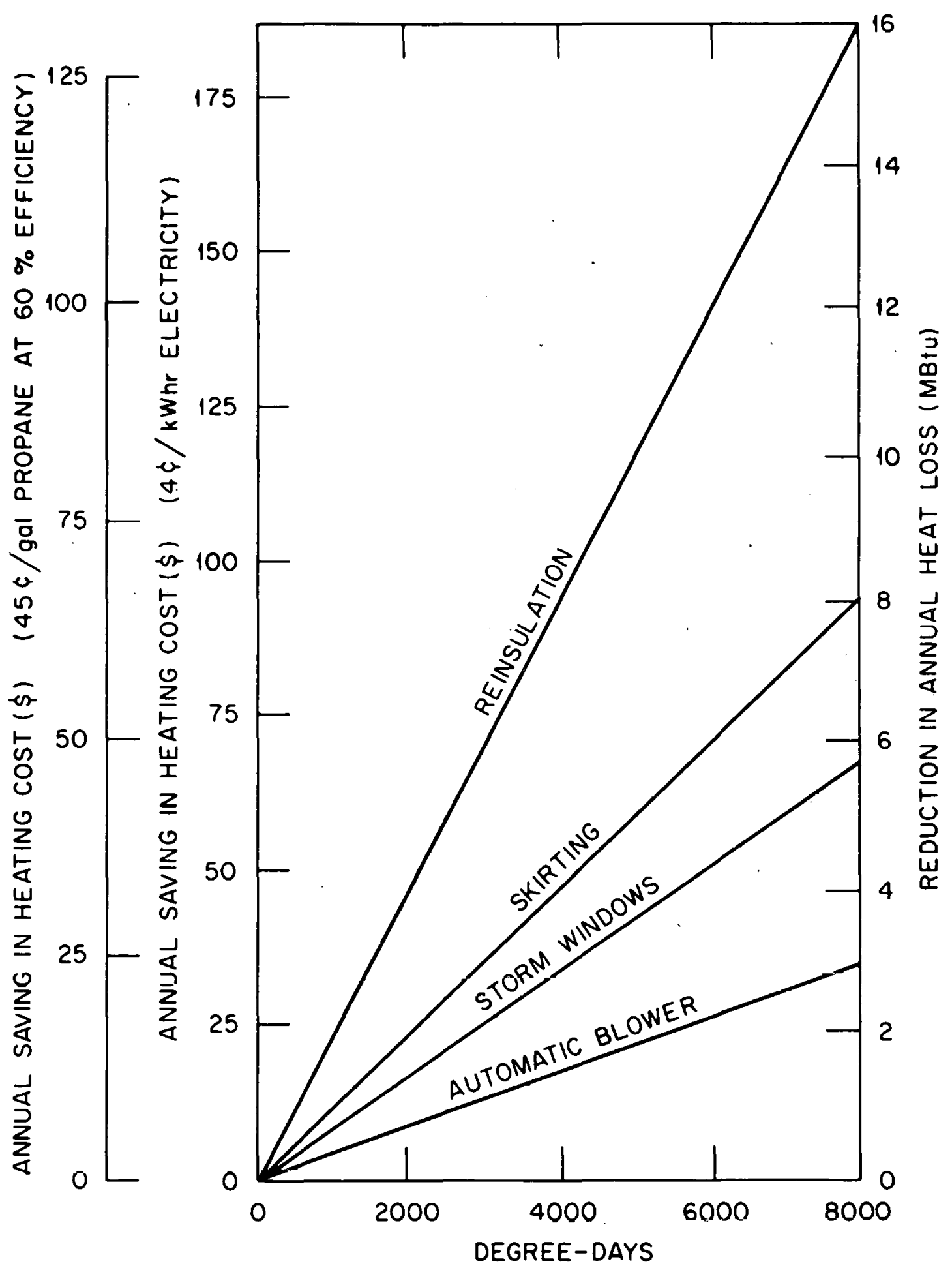

Fig. 10 Estimated annual savings in heating cost and reduction in annual heat loss. 
Table 4. Years needed for energy savings from heating seasons to pay for retrofit item*

\begin{tabular}{lcc}
\hline \multicolumn{1}{c}{ Item } & $\begin{array}{c}\text { Assumed cost } \\
(\$)\end{array}$ & Years \\
\hline \multirow{2}{*}{ Storm windows $\left\{\begin{array}{c}(10 \\
\text { Skirting }\end{array}\right.$} & 150 & 0.3 \\
Added insulation & 250 & 6.2 \\
\hline
\end{tabular}

*Assumptions: $12 \%$ annual interest rate, $4 \mathrm{c} / \mathrm{kWhr}$ electricity, and a 4000 degree-days heating season. 
and monthly payments of $M$ dollars is

$$
\mathrm{T}=\frac{\ln \left(\frac{\mathrm{M}}{\mathrm{M}-\mathrm{P} \cdot \mathrm{I} / 1200}\right)}{12 \ln (1+\mathrm{I} / 1200)} .
$$

No credit is taken either for escalation of energy costs or for savings realized during the cooling seasons (which would be significant for the insulation), both of which would reduce the pay back periods.

\section{CONCLUSIONS}

It was concluded that a reasonably simple second-order dynamic model of an uninhabited mobile home could be used to predict its heating energy usage when exposed to Oak Ridge weather. These predictions could be made with sufficient accuracy to determine energy savings due to the addition of retrofit items. Further work is needed to confirm predictions of cooling season energy savings. Because of the many variables involved and the risks of extrapolating from this one test series, it would not be prudent to make blanket recommendations to a mobile home owner on whether or not to add certain retrofit items. There are enough data and examples given, however, to get at least a rough idea of the expected savings.

\section{RECOMMENDATIONS FOR FUTURE WORK}

Although these tests indicate the savings that could be expected from construction changes and retrofits, they are limited to a single uninhabited mobile home in Oak Ridge weather. It would not be feasible to extrapolate these results to far different climates. Since effects of inhabitants, snow, and prevailing winds were not included in these tests, they are not included in the present model or its coefficients. 
It is the author's opinion that there are many good arguments for doing more experimental studies of mobile homes. In general, the credibility of good experimental data is much greater than that of calculations with theoretical models, espectally when many variable factors affect the results. Policy decisions for changing manufacturing standards and recommendations to the mobile home-owning public should be backed up by thorough research, since errors or misleading advice could be very expensive and embarrassing. Research and development costs less for energy conservation than for advanced energy sources, and is usually more cost effective. Finally, those who would stand to gain the most from mobile home energy conservation--the owners--are often in the most need of economic relief.

Several specific problems could be addressed by an extensive monitoring and analysis program, such as the variability of mobile home energy use characteristics as a function of mobile home construction and age differences, retrofit items, lower thermostat settings at night, differences in family living habits, and different climates. Such a program could be accomplished as follows:

1. Develop a compact data collection instrumentation package that could be installed in a mobile home to record weather data, inside temperature, and energy use data on a cassette tape.

2. Make $\sim 50$ of these units and install them in volunteer mobile homes in representative parts of the country.

3. Have each mobile home owner mail the cassette tape (monthly) for analysis, getting base case data (and variability) for each.

4. Add retrofit items (one at a time) to each mobile home, and determine the statistics of the resultant savings.

It would be prudent to begin with one or two prototype data systems installed locally, perhaps with additional monitoring, to ensure that no important variables are overlooked.

Further analysis of other retrofit items (such as awnings, zoning tests, sophisticated control schemes, solar heating assists, etc.) would be very worthwhile. More work on analysis of air conditioning tests is also needed to establish the total annual energy and cost savings resulting from retrofits. 


\section{REFERENCES}

1. Robert Hooke and T. A. Jeeves, Assoc. Computing Machining J. $\underline{\underline{8}}$, 212 (1961).

2. J. V. Wilson, Energy Usage and Conservation In Mobile Home Heating and Cooling, ORNL/NSF/EP-91 (August 1976).

10. ACKNOWLEDGMENT

The author is grateful to John C. Moyers of the ORNL Energy Division for his advice throughout the project, and especially for his assistance with Sect. 6, "Estimated Economic Gains from Retrofits." 
THIS PAGE

\section{WAS INTENTIONALLY LEFT BLANK}


ORNL/CON-9

\section{INTERNAL DISTRIBUTION}

\footnotetext{
1. R. K. Adams

2. S. I. Auerbach

3. T. D. Anderson

4-23. S. J. Ball

24. S. E. Beall

25. D. J. Bjornstad

26. C. J. Borkowski

27. J. R. Buchanan

28. R. S. Carlsmith

29. W. S. Chern

30. N. E. Clapp, Jr.

31. J. C. Cleveland

32. F. L. Culler

33. J. G. Delene

34. A. Domingarino

35. R. D. E11ison

36. G. G. Fee

37. H. C. Fischer

38. W. Fulkerson

39. G. S. Gill

40. W. R. Griffith

41. M. P. Guthrie

42. N. Hardin

43. V. O. Haynes

44. E. Hirst

45. E. C. Hise

46. P. L. Johnson

47. A. S. Holman

48. S. I. Kaplan
}

49. R. S. Livingston

50. C. D. Martin

51. J. W. Miche1

52. W. R. Mixon

53. J. C. Moyers

54. E. A. Nephew

55. L. C. Oakes

56. H. Postma

57. M. W. Rosenthal

58. T. H. Row

59. G. G. Slaughter

60. R. S. Stone

61. I. Splewak

62. R. L. Spore

63. E. G. Struxness

64. D. B. Trauger

65. G. U. Ulrikson

66. D. J. Walukas

67. J. V. Wilson

68. A. Zucker

69. ORNL Patent Office

70-71. Central Research Library

72. ORNL - Y-12 Technical Library Document Reference Section

73-76. Laboratory Records Department

77. Laboratory Records, ORNL R.C.

78. Blology Division Library

79-212. Energy Conservation Section

EXTERNAL DISTRIBUTION

213. Director, Research and Technical Support Division, ERDA, ORO

214. Institute of Energy Analysis, ORAU

215-501. External Energy Conservation Distribution Mailing List

502-528. Technical Information Center, ERDA, P.0. Box 62, Oak Ridge, Tennessee 37830 